\title{
The Maclagan family: six generations of service
}

\author{
D Doyle \\ Retired Consultant in Palliative Medicine, Edinburgh, UK
}

\begin{abstract}
The Maclagans were a Scots family from humble origins who produced famous physicians and surgeons (two of them presidents of Royal Colleges), ministers of religion (including one archbishop and several missionaries), a director of the Victoria \& Albert Museum, a famous anthropologist, many army officers, a leading Oxford historian, several town mayors and politicians. Their lasting legacies include many books, papers and reports, new university departments and degrees, a new and much-needed focus on public health and hygiene, the care of the mentally ill and the development of military medicine, as well as a heightened reputation for the Royal College of Physicians of Edinburgh and the Victoria \& Albert Museum, all seemingly achieved without thought for personal aggrandisement. People who knew the Maclagans well characterised them by their energy, vision, graciousness, humour and commitment to serving others and their Christian faith.
\end{abstract}

Correspondence to $D$ Doyle, 7 Kaimes Road, Edinburgh EHI2 6JR, UK

tel. $+44(0) 1313343168$ e-mail derekdoyle@waitrose.com

KEYWORDS Archbishop of York, Maclagan, Royal College of Physicians of Edinburgh, Royal College of Surgeons of Edinburgh,Victoria \& Albert Museum

DECLARATION OF INTERESTS No conflict of interests declared.

An article published in this journal as one of a series on 'Notable Fellows' of the Royal College of Physicians of Edinburgh (RCPE)' and an anthology of outstanding Fellows of the Royal College of Surgeons of Edinburgh (RCSEd) ${ }^{2}$ looked briefly at David Maclagan and his son, Andrew Douglas Maclagan, both famous as surgeons and physicians and past presidents of the two Royal Colleges of Edinburgh. This paper relates more about them and other equally famous family members, all brilliant, charismatic and influential leaders of men and servants of those in need.

The Maclagan family always claimed that the dynasty began with a David MacClaggan, who hailed from Tayside. Scotland, fought on the losing side in the 17/5 Jacobite Rebellion, then spent several years in England and died soon after settling in Edinburgh. His son Robert is today regarded as the patriarch of the dynasty, as so little is known about his father. Robert married his first wife, Anne Isobel Paterson, a doctor's daughter, in 1765. In 1780, when she died, he was working as a teller in a bank, Ramsay, Bernard and Co., in a $7 \mathrm{ft} \times 7 \mathrm{ft}$ luckenbooth (a locked shop) in Edinburgh's High Street. In 1783 he became a merchant and married Margaret Smetton, with whom he had one son, David. Robert changed their name to Maclagan (sometimes spelt with an upper case $L$ and at other times with a lower case one, possibly to dissociate themselves from the Jacobites). We look first at David, born in 1785, the year his father died.

\section{DAVID MACLAGAN (|785-|865)}

David (see Figure I) was the only one of Robert's five children to reach adulthood. He graduated MD from the University of Edinburgh in 1805 with a thesis entitled 'De sanitate tuenda'. Too young to join the army, he worked in

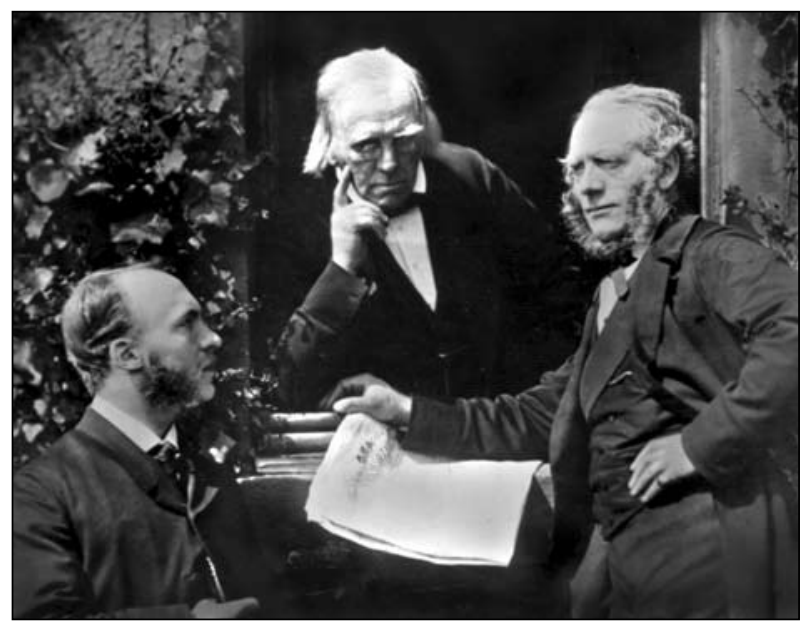

FIGURE I Robert (left), David (centre) and Andrew Douglas Maclagan (right) in a photograph by David Octavius Hill and Robert Adamson, c. 1850. (With kind permission of Christie's, London, (c) Christie's Images Limited.)

St George's Hospital in London, assisting at operations and gaining his MRCS Eng in I807. He then joined the 9 Ist Regiment and saw battle in 1809 at Walcheren, where of the 1,000 troops in his regiment less than one company survived their wounds and infections. Two years later, David was posted to Wellington's army in Portugal, seeing action at the battles of Badajoz, Salamanca, Vittoria, the Pyrenees, Nivelle and Nive. He was later awarded the Peninsular War medal with six clasps and promoted to 'Physician to the Forces', as well as being made responsible, at the invitation of the Portuguese government, for reorganising the medical services of their army - all this by the age of 29 .

David resigned from the army when Napoleon was exiled to Elba and his surgeon's pay was cut by half. He 


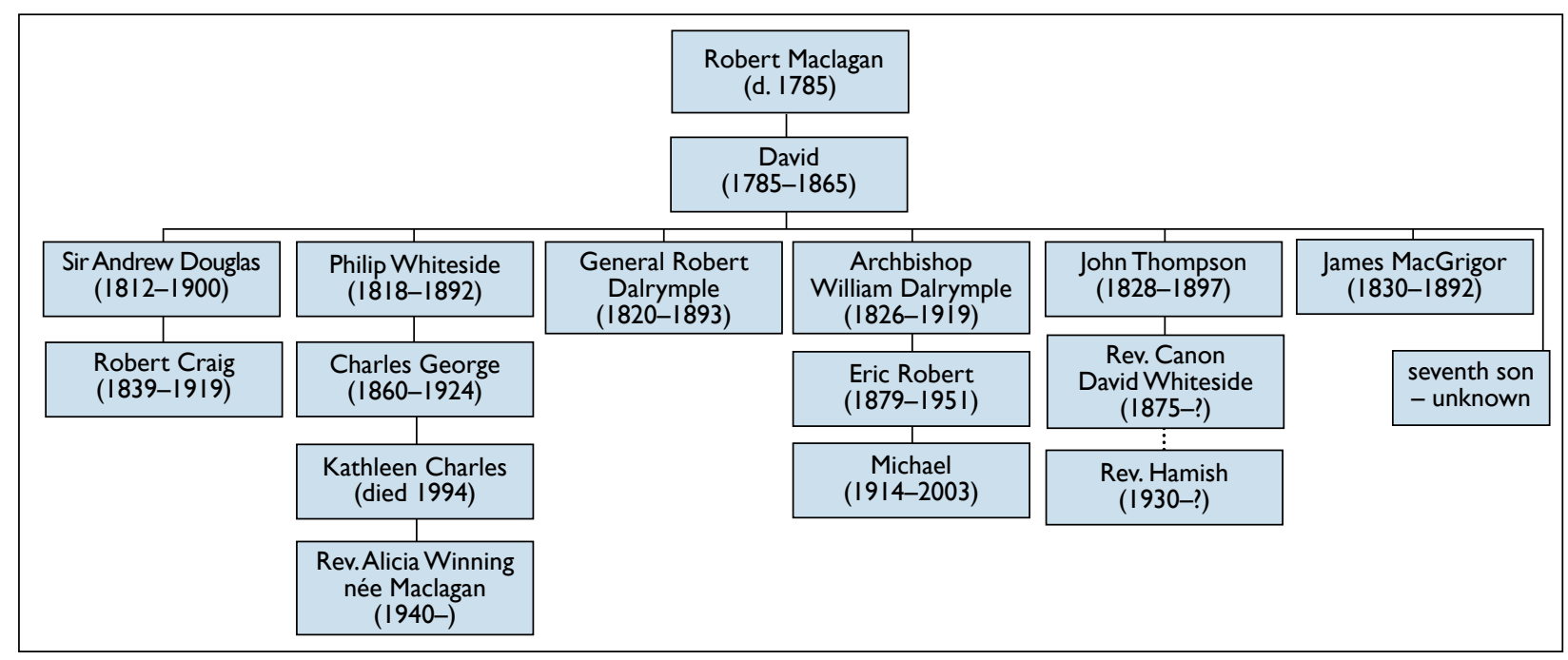

FIGURE 2 The Maclagan family tree, showing those family members mentioned in this paper.

bought No. 22 George Street in Edinburgh, where today stands the Royal Society of Edinburgh (RSE)..$^{3-5}$ Gaining his Fellowship of the RCSEd on 16 July 1816, David built up a thriving practice. It might be thought that, despite his distinguished military career, he would have been relatively unknown in Edinburgh, but that was not so. In 1815, shortly after leaving the army, he joined John Thomson,WE Alison, JH Davidson, JW Turner, J Murdoch and BB Buchanan, all famous Edinburgh doctors, to found the New Town Dispensary. ${ }^{6}$

In 1822 Edinburgh's first professor of military medicine, Professor John Thomson, resigned, according to some because he was not appointed to the Chair of Physic.' Three men applied for his post - David, George Ballingall (a surgeon in the Royal Infirmary) and James Borthwick (who was not a Fellow of the RCSEd). Ballingall was appointed, somewhat controversially in the light of David's experience and standing, and David became senior lecturer. ${ }^{7}$ Only ten years after gaining his FRCS Ed, David became President of the RCSEd and a deacon on the Town Council board. There followed his election as Fellow of the RSE and his appointment as Surgeon to the Queen in Scotland and Physician to the Army in Scotland.

It came as a surprise to many when in 1848, aged 63 and at the peak of his career, David gave up surgery to become a physician, becoming a Fellow of the RCPE on I May. Such a move was not unique. His eldest son, Douglas, had done the same in 1845 (although the RCPE Council minutes for that year do not mention him) ${ }^{8}$ Archibald Pitcairne, a famous physician of the earliest days of the RCPE, moved into surgery and became a distinguished lecturer before returning to medicine a few years later.

David was as famous, successful and honoured in medicine as he had been in surgery. In 1856 he became
President of the RCPE, guiding the College at a time when it was preoccupied with matters that today would be the preserve of the General Medical Council discipline, registration and the saga of all the Royal Colleges claiming the right to confer degrees. ${ }^{8}$

He remained an honorary Consultant Surgeon to the New Town Dispensary until late in life. It was also known as the Thistle Street Dispensary, as its address was 17a East Thistle Street (although its first report gave the address as 12 North James Street). It should not be confused with the Edinburgh Royal Public Dispensary, founded by Andrew Duncan in 1778. Sadly, relations between the two dispensaries were sometimes acrimonious.

David had seven sons, four becoming famous doctors and four serving in the army (Figure 2). He and his family worshipped in St George's Parish Church, now West Register House, built in $181 \mid$ in Edinburgh's Charlotte Square. ${ }^{9}$

\section{ANDREW DOUGLAS MACLAGAN (I8|2-| 900$)$}

David's wife Jane, the daughter of a general practitioner, hailed from Ayr, and it was there that Douglas (Figure 3) was born when his father was serving in Portugal. He qualified in medicine with the Licentiate of the RCS Ed in 1831. He then graduated MD from the University of Edinburgh in 1833 (with a thesis on biliary calculi) and on 19 June that year became FRCS Ed, exempt from further training or examination because his father was a Fellow. Douglas then studied in London, Paris and Berlin before purchasing a house in Edinburgh's Heriot Row and setting up in practice. Shortly thereafter he was appointed Assistant Surgeon at Edinburgh's Royal Infirmary.

According to the memoirs of Sir James Young Simpson, Douglas's 'studies' abroad were spread over only three 


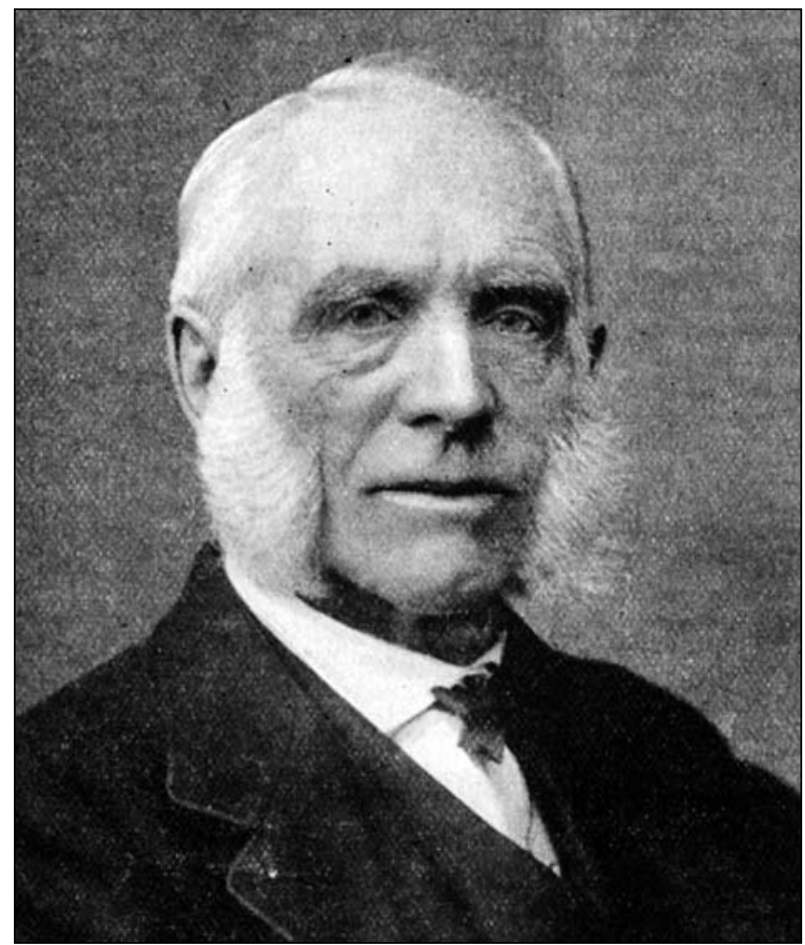

FIGURE 3 Photograph of Andrew Douglas Maclagan from his British Medical Journal obituary." (With thanks to the BMJ.)

months and consisted of visits, usually lasting a few hours, to famous doctors or clinics (probably known to his father who may have facilitated the meetings). He does not seem to have had any formal tutoring or 'hands-on' training. Simpson obviously enjoyed Douglas's company and the people Douglas could introduce him to. They were made most welcome, considering that at this time neither had made a name for themselves and Douglas had just graduated. ${ }^{10}$

Like many others, Douglas was a correspondent of Charles Darwin, Johann Wolfgang von Goethe and Walter Scott, although none of the letters that passed between them have been seen by the author. Some years later, he was elected President of the RCSEd, President of the Harveian Society and, later still, President of the RSE."

In 1845 , aged 33 , he gave up surgery and became a Fellow of the RCPE and a lecturer and researcher on materia medica in the Extra-Mural Medical School, a post he held for 18 years. After that he was appointed Professor of Medical Jurisprudence and Medical Police, leading to his national reputation as a toxicologist. Douglas held that position until he retired in 1896. His specialist evidence in many major trials proved decisive. He taught his students:

A dead body tells no tales except those it whispers to the quick ear of the scientific expert, by him to be reported to the proper quarter."
Douglas was both a colleague and close friend of Professor Sir Robert Christison, one of the leading toxicologists of his day. While still practising as a surgeon, he assisted Christison when giving evidence for the prosecution of William Burke, who, with his associate William Hare, had murdered to procure bodies for dissection by Robert Knox in the Extra-Mural Medical School in 1829. The year 1849 saw the publication of Douglas's seminal work on toxicology. ${ }^{12}$ In 1857 he gave crucial toxicological evidence in the trial of Madeleine Smith, which ended with the uniquely Scottish verdict of 'not proven', and in 1878 he gave decisive evidence in the trial of Eugene Marie Chantrelle, who was convicted of murder by poisoning. Chantrelle was the first person to be hanged in Edinburgh's Calton Jail.

Douglas was instrumental in establishing a public health laboratory in Edinburgh and separating the subject of public health from that of forensic medicine. He also persuaded the University of Edinburgh to create the first Chair of Public Health in 1895. This was followed by his introduction of the BSc and MSc degrees in the subject. While Professor of Forensic Medicine and Public Health he was ex officio an Assistant Professor of Clinical Medicine, eventually becoming Senior Professor of Clinical Medicine, lecturing almost entirely on dermatology. Indeed, it was largely as a result of his work that a separate department of dermatology was set up in Edinburgh. ${ }^{10}$

Like his father, Douglas became a popular President of the RCPE and was re-elected for a second term, which was much taken up with improving the care of the mentally ill under a new Lunacy Act and with improving medical education. During his Presidency, the College's Cullen Prize was created. ${ }^{8}$ Both Douglas and his father continued to pay their subscriptions to the RCSEd, enabling them to continue to put FRCS Ed after their names until their deaths. ${ }^{13}$

Like so many members of the dynasty, Douglas was fascinated by the army and worked hard to develop the volunteer movement as Surgeon Major of the Queen's Brigade and Brigade Surgeon of the Royal Company of Archers, the Queen's Bodyguard for Scotland. Multitalented, he read the Greek and Latin classics, and was a skilled instrumentalist, songwriter and singer in the Edinburgh University Medical Society. ${ }^{14} \mathrm{He}$ was dubbed 'Poet Laureate of the New Town Dispensary': ${ }^{15}$ many of his poems were read for the first time at dinners where he was an ever-popular guest of honour; others were only discovered after his death and are still available. ${ }^{14}$ The list of his talents, interests and contributions to many lives seems endless." Many of his lecture notes can be seen in the special collections section of Edinburgh University Library. 


\section{PHILIP WHITESIDE MACLAGAN (I8|8-92)}

From his earliest days, Philip, Douglas's brother and the second-born son of David, was fascinated by natural science and botany. George Johnston, a general practitioner working in Berwick-upon-Tweed, offered a copy of his book A Flora of Berwick-upon-Tweed ${ }^{16}$ to any young botanist who could send him 20 British plants not named in the book. The young Philip immediately sent him 50 such specimens. They met, started to correspond, and soon Philip was enjoying holidays in Berwick and subsequently married Johnston's daughter. After qualifying in 1840 (his MD thesis was on Entozoa), he was appointed Assistant Surgeon of the Canadian Rifles and then Surgeon of the 20th Regiment, finally returning to Berwick in 1852. Philip went into partnership with his father-in-law, but Johnston died soon after, leaving him to run the practice for the next 40 years, using rooms in his own house for consulting and waiting. Philip eventually took his own son into partnership.

Many records speak of Philip's kindness and gentlemanly manner which made him very popular and an upstanding figure in the local church community. In addition to the son who joined him in practice, another became a solicitor and a third served as a missionary in China, alongside one of his five sisters. ${ }^{17}$

\section{ROBERT DALRYMPLE MACLAGAN (I820-93)}

David's third son, Robert, spent his life in the army. After schooling at Edinburgh Academy (founded shortly after he was born) he went to Addiscombe College, the equivalent of today's Sandhurst for officer cadets intending to enter the Indian Army. Aged 19, Robert joined the Bengal Engineers and served in the Sikh War. Later he was appointed Principal of the Government Engineering College in Roorkee, and from 1860 to 1879 was Chief Engineer and Secretary to the Punjab Public Works Department. ${ }^{18} \mathrm{He}$ married Patricia Gilmour in 1866 and they had six children, five boys and one girl. Although Robert stayed in India until 1879, his wife and children returned to Britain for the education of the children, living in Edinburgh for a few months, then in Cheltenham where they bought a house. One son rose to the rank of colonel in the army and another was knighted. The few records that exist tell us little about Robert, except that he was 'very religious'. ${ }^{18,19}$

\section{WILLIAM DALRYMPLE MACLAGAN (|826-|9|0)}

David's fourth son, William, attended the Royal High School in Edinburgh and then the faculty of Law at Edinburgh University, as a pupil of Messrs. Douglas and Co. In 1847 he became a lieutenant in the Indian Army but had to resign on health grounds after only five years. In 1852 he went to Peterhouse College, Cambridge, graduating four years later in mathematics, and was immediately made a Deacon of the Church of England. After serving many parishes he became Bishop of Lichfield in 1878 and four years later Archbishop of York. Within three years he had visited all 650 parishes and their priests as well as establishing a training college for clergy. The highlight of his career in the church was in 1902 when he crowned Alexandra of Denmark, wife of King Edward VII. ${ }^{20}$ In 1897 he had paid a private visit to Russia where he was warmly received by the Russian Orthodox Church and had an audience with Tsar Nicolas II.

William was appointed to the Privy Council in 1901.As a High Churchman, he had to play down his private beliefs (on the use of incense and other ritualistic practices) in loyalty to William Temple, Archbishop of Canterbury. ${ }^{21,22}$ A great disappointment to him was the failure to create two new dioceses since, as he said himself, when serving in York he had been more Bishop than Archbishop because of the large population and territory to be served. William even offered $£ I, 000$ out of his own income to fund each new diocese, but it was not until 19/4 that a bishop was appointed to Sheffield.

William will be remembered for his diplomatic and pastoral skills, the hymns, books and theological and pastoral papers he wrote. ${ }^{23}$ His second wife, Augusta, a daughter of Viscount Barrington, made him a wealthy member of the aristocracy and produced a son, Eric, who was to become Director of the Victoria and Albert Museum (V\&A).

\section{JAMES MCGRIGOR MACLAGAN (I 830-92)}

David's youngest son, James attended Edinburgh's Royal High School and University, graduating MD in I85I (with a thesis on autumn crocus, the source of colchicine for gout). He served in the Indian Army as an Assistant Surgeon, but ill health (the details of which are not recorded) cut short his service. James then engaged in private practice in Cromer and Mexborough before moving into public health, serving as medical officer for health for Hexham and Haltwhistle until 1890. His resignation was precipitated by a reduction in his salary from $£ 300$ to $£ 200$ per year and the suggestion that he augment this with private practice, something he felt unqualified to do after so many years away from the bedside. It was as he was leaving the meeting where all of this was discussed that he fell, breaking his femur. It healed but left him with a limp and much impaired health.

Although he was never as well known as his father and brothers, James held many positions in the British Medical Association and the Northern Counties Association of Medical Officers of Health and was considered an authority on water supply, housing and sanitation as adjudged by his 17 annual reports. Curiously, his death was recorded as being caused by 'chronic 
cerebritis supervening on an attack of hemiplegia'. ${ }^{24} \mathrm{We}$ turn now to members of the next generation, starting with one of Douglas's sons.

\section{ROBERT CRAIG MACLAGAN (|839-|9|9)}

Following family tradition, Robert Craig attended Edinburgh's Royal High School and its university, graduating MD with high commendation in 1860 (with a thesis on Hyoscyamus niger). In 1865 he became a Member of the RCPE and two years later a Fellow, as well as being elected a Fellow of the RSE. His name first became well known through his papers describing the arsenic eaters of Styria, mountain people who regularly ate arsenic spread on bread. ${ }^{25,26}$ The men claimed it aided their breathing on high climbs, the women that it increased their girth and gave them flushed faces, features much appreciated by their husbands. On two separate visits, Robert Craig interviewed locals and their doctors who corroborated what the peasants had said. $\mathrm{He}$ also had urine specimens examined in Scotland, all proving positive for arsenic. His papers may have reduced some of the medical profession's reservations about arsenic and led to further testing of the arsenic in Fowler's Solution for any therapeutic potential. ${ }^{27}$

Early in life Robert Craig began to lose his hearing, and it was probably this that gradually led him from the bedside into medical research. Such research was only a very small part of his overall contribution to our knowledge of the history, folklore, customs and language of Scotland, leading him to be recognised as a great anthropologist. Assisted by their knowledge of Gaelic, Robert Craig and the team he gathered round him, produced more than 9,000 manuscripts on the Scotland of the 16th to 19th centuries, now all in the possession of the Department of Celtic and Scottish Studies of the University of Edinburgh. ${ }^{28}$

Although he never served in the regular army, Robert Craig nevertheless joined the No. 4 Company Volunteer Battalion, Royal Scots, later becoming colonel of the 5th Battalion and honorary colonel, a rank he eventually resigned in 1909. Another cause he energetically supported, and helped to found, was the Scottish Association for the Medical Education of Women.

Those who knew him or worked with him described him as a man of great charm, a delight to know, with a carriage of distinction and quiet authority - much as his father was always described. ${ }^{29}$

\section{ERIC ROBERT DALRYMPLE MACLAGAN (I879-I95I)}

Eric, Archbishop Maclagan's son by his second marriage, was educated at Winchester and Christ Church, Oxford, where he read classics. He worked his way up the ranks of the V\&A, first in the textiles department and then in

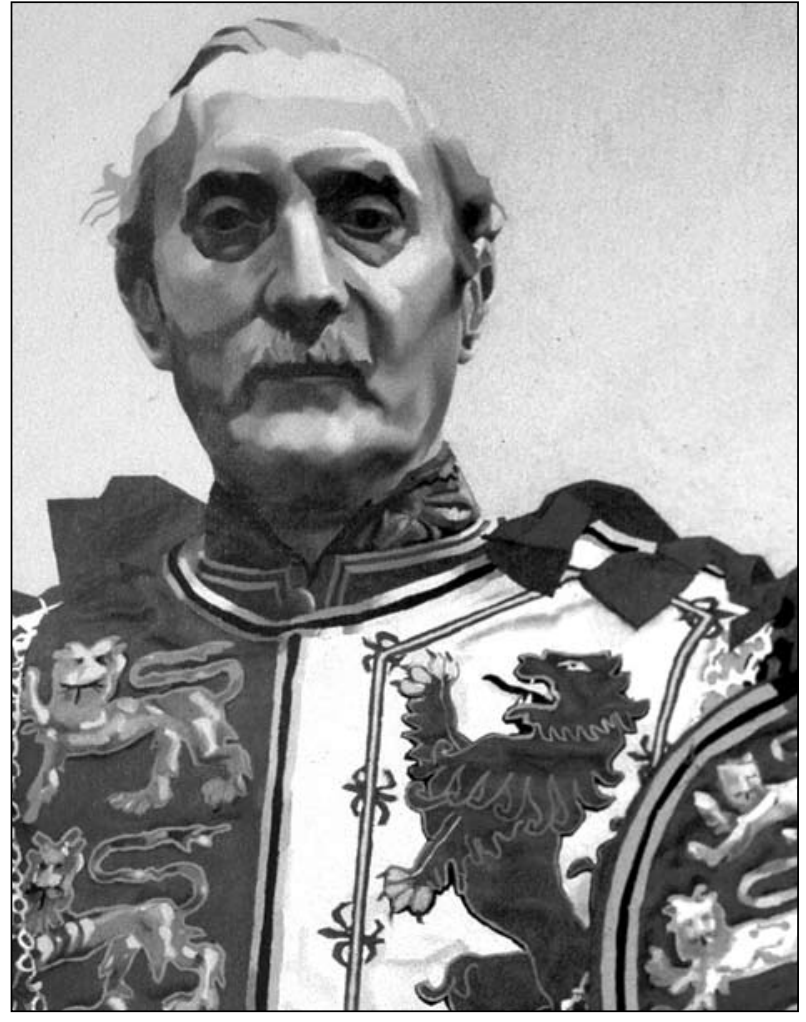

FIGURE 4 A portrait of Michael Maclagan in his regalia as Richmond Herald. (With thanks to Trinity College, Oxford.)

the department of architecture and sculpture, until he was temporarily seconded to the Foreign Office in 1916 and later the Ministry of Information. He finally became head of the Bureau of the Ministry of Information in Paris and its controller for France, using his fluency in French (and German). He was made CBE in 1919.30

By 1924 Eric had been appointed Director of the V\&A and in succeeding years helped make it what it is today - one of the country's, indeed the world's, greatest museums. He wrote many books, held numerous appointments and was personally responsible for some of the most important museum exhibitions. In 1945 he was appointed KCVO. To the end of his life his favourite pastime was reading Greek and Latin.

\section{MICHAEL MACLAGAN (19|4-2003)}

It is logical to turn now to Eric's son, Michael, who might be described as the quintessential Maclagan - tall and stately (at $6 \mathrm{ft} 3$ in), looking every inch the army officer (he had been a major), brilliant academically, a polyglot (speaking fluent Italian, French, German and Serbo-Croat and reading Greek and Latin), a charismatic lecturer in history, and renowned for his loyalty to his friends, students and Trinity College, Oxford, his college of 40 years. He is immortalised in an oil portrait in his full regalia as Richmond Herald in the entrance to Trinity College dining hall (Figure 4). ${ }^{31}$ 
Michael served the Oxford Union for around 60 years as Senior Librarian and Trustee, occasionally taking part in debates. He was a university-appointed alderman on the Oxford City Council and held the offices of Sheriff in 1964-5 and Lord Mayor in 1970-I. He considered a career in national politics as a Tory MP until dissuaded by his second wife, who knew that he was temperamentally unsuited for such a life. ${ }^{29}$

Michael experienced considerable sadness in his life.The death of his younger brother, Gerald, in the Second World War, affected him deeply. At roughly the same time his first marriage, to his cousin Brenda Alexander, a society beauty, broke down. Later on, his second son, Andrew, died of leukaemia at the age of 26. Michael found much happiness, however, in his second marriage, to Jean Garnett, whom he had met during his time at the War Office and married in 1949. They had two daughters and lived in the former home of the author JRR Tolkien in north Oxford, where they entertained generations of Trinity undergraduates and postgraduates. Michael died ten days after Jean in 2003.

\section{THE MACLAGANS AND THE CHURCH}

While William Dalrymple, Archbishop of York, may have been the most famous clerical member of the dynasty he was by no means the only one who served the Church. John Thompson Maclagan (1828-97) was for many years Secretary for Foreign Missions of the Church of Scotland, while mention has already been made of a son and daughter of Philip serving as missionaries.

The Rev. David Whiteside Maclagan (born in 1875) qualified in medicine, then in divinity, becoming a vicar of the Church of England in Worcester. He wrote a booklet which is still available called $A$ popular guide to Tewkesbury Abbey. ${ }^{32}$ A relative, the Rev. Hamish Maclagan (born 1930), also became a vicar in Worcester and retired there. Finally, mention must be made of one of the first women to be ordained into the ministry of the Church of Scotland, Rev. Alicia Ann Winning née Maclagan, born in 1940 to Kathleen Maclagan of Berwick and now retired.

\section{DISCUSSION}

The histories of David and Douglas, moving from surgery to medicine, are fascinating but different in several respects. David had had more than two years of training at St George's Hospital, London, and vast experience of battlefield surgery in the army, followed by 32 years as an Edinburgh surgeon, before he moved into clinical medicine. Douglas, on the other hand, had no apprenticeship, was awarded his FRCS Ed in the same year he graduated MD and only worked as an Edinburgh surgeon for 12 years, leaving not to practise general internal medicine like his father, but to teach and research materia medica and pursue his fascination with toxicology.

Did Douglas ever enjoy surgery as much as his father had done? There is no evidence whatsoever of either man being disillusioned with surgery, although it would be understandable if they felt they had performed enough operations without anaesthesia or antisepsis. Nor is there evidence of discord within the RCSEd or disappointment with it or of failing private practices. Indeed, they may have brought the two colleges closer together. There is no evidence that they changed the course of their careers because of scandal, jealousies, personality conflicts or professional disappointments. On the contrary, all writers attest to their commitment to both colleges. Both David and Douglas made outstanding creative contributions to the University of Edinburgh, creating new departments, introducing new degrees, developing better co-operation between departments and stimulating research.

The Maclagans shared many common attributes. Obituaries and other accounts of them frequently use the same descriptions - 'brilliant,' 'gracious', 'charming', 'dignified', 'honourable', 'deeply respected and appreciated', 'a natural leader', 'highly influential' and 'religious'. None of them seem to have sought office or title for personal aggrandisement, although, certainly in the case of David and Douglas, they may well have seen more opportunities as physicians to change the course of medicine than they had as surgeons.

Another common thread is the Maclagans' strong Christian faith, whether they worked in the army, in medicine or in the Church itself. Those who stayed in Edinburgh worshipped principally in St George's West or Greyfriars churches, usually serving as Elders. Others, as we have seen, worked in or for overseas missions. All were members of the established church, whether in Scotland or England.

Also surprising is the number who served in the Army or the Volunteers, in several cases after qualifying in medicine. It can hardly have been because of the glamour of the uniform, since several of them saw actice service and were called upon to relieve appalling suffering. All were elected leaders within their professions. Their responsibilities must have been heavy, many decisions difficult and calling for diplomatic and communications skills.

In spite of the size of the dynasty and its diaspora, they were a family in touch with each other. We know, for example, that two of the pallbearers at Douglas's funeral were the Archbishop of York and Robert Craig Macglagan. Several obituaries name the family members present at other funerals, particularly those of wives. 
Acknowledgements The author is indebted to Professor $\mathrm{MH}$ Kaufman for his seminal works on many of those named in this paper, and the librarians of the RCPE, the

\section{REFERENCES}

I Doyle D Past presidents: the Maclagan dynasty.J R Coll Physicians Edinb 2007; 37:48.

2 David Maclagan (1785-1865), Andrew Douglas Maclagan (18I21900). In: Macintyre I, MacLaren I, editors. Surgeons' lives: an anthology of biographies of college fellows over 500 years. Edinburgh: Royal College of Surgeons of Edinburgh; 2005. p.82,98.

3 Kaufman MH. Dr David Maclagan (1785-1865): distinguished Military Surgeon, President of both the Royal College of Surgeons and Royal College Physicians of Edinburgh, founder of a medical and military dynasty.J Med Biogr 2006; 14:75-83.

4 Obituary: Dr David Maclagan. Edinb Med J 1865; I I:94.

5 Obituary: Dr David Maclagan. Lancet I865; June 17:665.

6 Checkland O. Philanthropy in Victorian Scotland. Edinburgh: John Donald; 1980. p.202-3.

7 Kaufman MH. The Regius Chair of Military Surgery in the University of Edinburgh 1806-55. Amsterdam and New York: Rodopi; 2003.

8 Minutes of the Council of the Royal College of Physicians of Edinburgh: Book 2 (3 Nov 185I-7 Feb 1857) Book 3 (7 Feb 1857-18 Oct 1959), Book 7 (24 July 1883-3 Dec 1885), Book 8 (25 Dec I885-30 Mar 1888). Edinburgh: RCPE archives; I85|-88.

9 Keay J, Keay J, editors. Collins encyclopaedia of Scotland. London Harper Collins; 1994.

10 Duns J. Memoir of Sir James Y. Simpson, Bart. Edinburgh: Edmonston and Douglas; 1873. p.46-63.

I I Obituary: Sir Andrew Douglas Maclagan, MD, FRCPE, FRCSE, LLD (Edinburgh and Glasgow). Br Med J 1900;1:935-7. doi:10.1136/ bmj.I.2050.935

12 Maclagan AD. Cases of poisoning with remarks. Edinburgh: Sutherland and Knox; 1849

13 College Minutes of the Royal College of Surgeons of Edinburgh Records 9/10 (I826-28) and Records I4/I5 (|859-6I). Edinburgh: RCSE archives; |826-61.

14 Maclagan AD. Chancellor Inglis (in honour of the Right Hon. John Inglis, late Lord Justice General and Chancellor of Edinburgh University). In: Miller C. The Scottish students' song book. Glasgow: Bayley and Ferguson; I891.

15 Maclagan AD. Nugae canorae medicae: lays by the poet laureate of the New Town Dispensary. Edinburgh: Edmonston and Douglas; 1862.
University of Edinburgh, the National Library of Scotland and the RCSEd and the Archivist of York Minster.

I6 Johnston G. A flora of Berwick-upon-Tweed. Edinburgh: J Carfrae and son; 1829.

17 Obituary: Philip Whiteside Maclagan, MD Ed. Brit Med J 1892; I:I335-6. doi:I0.I I36/bmj.I.I642.I335

I8 Broadfoot W. One of a remarkable family: General Robert Maclagan, RE. Blackwood's Edinburgh Magazine 1894; I56:247-53.

19 Diaries and miscellaneous papers of General Robert Maclagan |84|-82. Cambridge University Centre for South Asian Studies.

20 How FD. Archbishop Maclagan: Being a Memoir of the most Reverend the Right Honorable William Dalrymple Maclagan DD, Archbishop of York and Primate of England. London:Wells Gardner and Co.; 1911 .

21 Temple F, Maclagan WD. Answer of the Archbishops of Canterbury and York to the Bull Apostolicae Curae of H. H. Leo XIII. London: I897.

22 Maclagan WD. On reservation of Sacrament. London: Macmillan and Co.; 1900.

23 Maclagan WD. Hymns and hymn tunes by the late Archbishop MacLagan. London: Novello and Co.; 1915.

24 Obituary: James Mcgrigor Maclagan, MD, LRCS Edin. Br Med J I892; I:I99-200. doi:I0.1 136/bmj.I.I62I.199-a

25 Maclagan RC. On the arsenic eaters of Styria. Edinb Med J I864; 10:200-7.

26 Maclagan RC.Arsenic-eaters of Styria. Edinb Med J 1875; I:526-8.

27 Doyle D. Notoriety to respectability: a short history of arsenic prior to its present day use in haematology. Br J Haematol 2009; |45:309-17. doi:I0.I I I /j. I365-2|4I.2009.07623.x

28 Papers of RC Maclagan. Archives of the Department of Scottish and Celtic Studies, University of Edinburgh.

29 Obituary: Robert Craig Maclagan, MD, FRCP Edin. Br Med J 1919: 2:93.

30 Maclagan, Sir Eric Robert Dalrymple (1879-195I). In: Dictionary of National Biography. Oxford: Oxford University Press; 2004.

31 Obituary: Michael Maclagan. Daily Telegraph, I6 Sep 2003. Available from: http://www.telegraph.co.uk/news/obituaries/I44I535/ Michael-Maclagan.html

32 Maclagan DW. A popular guide to Tewkesbury Abbey. Gloucester: British Publishing Co; 1943.

\section{EXAM PREPARATION COURSES: Please advise your trainee colleagues}

\section{MRCPCH REVISION COURSES}

\section{VIDEO COURSE}

II October 2010

65 high-quality videos

Fee: $£ 200$

\section{ETHICS AND COMMUNICATION} SKILLS COURSE

\section{I4-I5 October 2010}

- Small-group communication scenarios (including phone conversations)

- Fee: $£ 300$

\section{To book or for further information:}

Tel: 0।3। 2473607

Fax: 0131 2204393

Email: c.gray@rcpe.ac.uk 